\title{
Edward Albee's The Zoo Story: Echo/es of Contemporary Subversive Culture
}

\author{
Naqibun Nabi (Corresponding author) \\ Department of English, Comilla University \\ Kotbari, Comilla-3506, Bangladesh \\ E-mail: nabi0462@gmail.com \\ Firoz Ahmed \\ Department of English, Comilla University \\ Kotbari, Comilla-3506, Bangladesh \\ E-mail: firozahmed093@gmail.com
}

Doi:10.7575/aiac.alls.v.7n.1p.235

URL: http://dx.doi.org/10.7575/aiac.alls.v.7n.1p.235
Received: 14/10/2015

Accepted: 21/12/2015

\begin{abstract}
The post-world war II American social and cultural setting was ambiguously featured with enforced conformity in the name of prosperity and Americanization of the nation. Despite of this fact, American writers, especially, dramatists conveyed their message against this fixation through variety and intellectuality. Edward Albee's The Zoo Story is one of those literary assets which dedicatedly cut through the illusions of contemporary American social and cultural ethos. Here, his characters are seen struggling constantly with their insecurities and existential angst in the society. He presents America, the so-called 'Land of Free and Home of Braves' (note 1), in such a portrayal that unveils the traps of cages and confinement underneath. The target of this paper is to trace Edward Albee's heightened awareness about the postwar American socio-cultural reality evident in The Zoo Story. It also looks for the voice in which the text echoes out the anti-communist, materialistic, gender-coded boundaries, coupled with paradoxical media representations, religious bordering and how Albee challenges these issues with an anti-establishment tone.
\end{abstract}

Keywords: subversive culture, anti-communism, media, religion and homosexuality

\section{Introduction}

Edward Albee's The Zoo Story potentially opens a chance to be interpreted as a critique of the American society, and its ambiguous dominant culture. In The Zoo Story Albee presents two characters who belong to two different far ends of the same post-war American society. Peter, seemingly comfortable in his own social status, is passing an undisturbed afternoon at New York central park, when suddenly, Jerry, the other protagonist, intrudes amidst Peter's solitary moments. Eventually, Jerry invokes Peter to listen to his very own story and through their further conversation both of them come across to experience the absurd 'zoo' world. Finally, Jerry provokes Peter in many ways to face the realities unknown to him which results into uncovering the mask that Peter's contemporary American society has been wearing. Albee's target was to criticize the contemporary socio-cultural falsity through Jerry and Peter's encounter. The 'zoo' referred by Jerry is the symbolic representation of the contemporary society where individuals are condemned into cages made of dominant social and cultural norms, values, traditions and beliefs that deceptively overlook controversial issues of post-war American society, for instance, ravishing consumerism, class distinction, minority issues, civil rights, and so on. Thus, at the end of the drama where Peter stabs Jerry to death, Jerry's attempt was to unleash the animal inside of Peter which indicates the dehumanization process of American society formulated by the politicized cultural embodiments.

In the post war decades, America was constantly changing on political, social, cultural strands as Fredrick R. Karl (2004) says, "change was becoming so much more rapid that it could no longer be readily assimilated. The sheer pace of change was so disruptive; it was soon conflated with loss of values or associated with conspiracy and subversion" (p.24). Apparently, the society seemed culturally conservative reflecting traditional and religious beliefs like church, community, marriage, and family. However, the ambiguity was evident when these beliefs were being disseminated publicly through media and cultural embodiments to serve two very deceptive purposes. One was to confirm unquestionable conformity in anti-communist nationalistic view of new America, so that it can easily manipulate the public to adopt a capitalistic consumer culture. The second purpose was to disregard the 'other America' created inside the new post-war America that constantly came up with issues for instance, civil rights, women rights, gay and lesbian rights and religious rights. A counter culture against the establishment rose up at that time, which was strategically disregarded by the contemporary socio-cultural practices, to represent the questionable issues into unquestionable ones, as "the civil rights, poisonous racial and minority issues and run away corporate power would expose all the fault lines of the country" (Karl, 2004, p.23). Like his contemporary literary companions Allen Ginsberg, Tennessee Williams, 
Arthur Miller, O'Neil and many others, Edward Albee also ventured in that post war American society, particularly in the decades of $50 \mathrm{~s}$ and $60 \mathrm{~s}$, experienced that 'other America' which was most obviously initiated from the new subversive cultural patterns radically created from the new establishments of post-war American socio-cultural platform. Albee's early one-act plays were "attacking the cherished myths of his own country" (Kolin, 2005, p.16). His characters in The Zoo Story are alienated from their society and sometimes from their own selves, as a consequence of the modernist extravagant culture of materialism and social classes. Therefore, "Albee's targets were materialism, racism, artificial values, complacency, lack of communication, and the debilitating effects of illusions". (Kolin, 2005, p.16)

This paper attempts to study, particularly, the subversive post-World War II American society and its culture echoing in Edward Albee's play The Zoo Story. Major political turning points, rapid modern approaches to life styles, evolving social ethos, media uprising with the permanence of the wonder machine called television, and burning issues regarding gender and sexuality were the identifying features of 50s and 60s in America. The process of Americanization was in pursuit under these events and issues. The Zoo Story tries to look underneath this cloak of Americanization to reinterpret it from a different angle to show how much distorted the society and its norms are. The foremost concern of this paper is to identify and address echo/es like, anti-communist political attitude fostering capitalistic conformity, television used as a weapon to politicize the representation of Americanization in an unquestionable way, minority issues created through sexual and even religious preferences in the text to understand the contemporary socio-cultural context.

\section{Echo/es of Anti-communist, Capitalist, and Patriarchic Cultural Attitudes}

Bigsby asserts that The Zoo Story is "socially derived" (as cited in Horn, 2009, p.82), as Albee wrote it in his early career during the post-war period. However, as the time was critical for America, major changes were occurring in a very fast pace particularly in $50 \mathrm{~s}$ and $60 \mathrm{~s}$. Though the war was over and hope for future was there but the cold war against Soviet Union was brewing tension. In the early 50s republican senator Joseph McCarthy and his infamous army 'Red Scare' launched a crusade against communism and its allies. The rampant of McCarthyism ran almost all over America, leaving a deep trail over the political history of America. The anti-communist crusade and a dubious public sentiment regarding it affected the socio-cultural life of post-war America. Hunting down the 'godless' communists, stopped and made people afraid about supporting any kind of ethos or conception related to communism which paved the way to absolute conformity under anti-communist command. Karl (2004) notes, "Such establishments created radically new cultural patterns with often undesirable consequences" (p.31). It was quiet alarming as Karl (2004) states again, "America was becoming more conservative more reliant on traditional beliefs, even religious and more narrowly American, nationalistic even chauvinistic" (p.22). The cultural norm was to follow a coherent and homogeneous lifestyle, based on a promise of American prosperity. People started their post-war life with traditional and conservativeness along with homogeneous codes by means of church, community and family inspired by authority.

The American masculine ethos of patriarchal society also helped to conform readily to these cultural codes unquestionably. So, the anti-communist political chauvinism, homogeneous social, cultural and religious codes of lifestyle, the patriarchal psyche and heteronormative identity made American people fixed to the process of Americanization which confirms the participation in undoubted conformity to American dream and prosperity. Karl (2004) proclaims about the period that there "is a sense of counterfeit, the deceptive, the fraudulent, the artificial and the imitation" (p.21), which reveals the ambiguous and double faced construction of ethos and codes of American culture and society. Finally, Karl (2004) presumes "the final legacy of McCarthyism was that government had proved itself the enemy of government, an idea which escalated in the $60 \mathrm{~s}$ into the counterculture." (p. 36). Thus, the existence of a divergent anti-establishment cultural stand can be assumed in that period. "Such discontent began to merge with a more widespread rebellion in the early 60s" (Karl, 2004, p. 36), regarding ethnic, gender and sexuality based identity issues, civil rights issues; paradoxical homogeneity which started personifying that counterculture.

Edward Albee experienced and caught that fire of 50s and 60s in his early plays. In The Zoo Story, as Kolin (2005) states, "Albee's voice was distinctively American, pressing for social change and reform." (p.17). And as a critique of the ambiguous and double faced construction of American cultural code in his society, Albee's works were remarked as the "modern capacity for ugliness, hate and evil, Albee's plays seem to say, lurks beneath the well-brushed veneer of post-war American society” (Bell, 2004, p.124). More indicatively, Kolin (2005) remarks "The Zoo Story politically pummeled American conformity with scathing satire and ideological fervor" (p.16) that comes to meaning when Peter, the 'bourgeoisie gentleman' from the establishment, met with the 'anti-establishment hero', Jerry. On their first meeting, their social classes are prevalent through their attitudes and body language. The apparel with tweeds, hornrimmed glass smoking pipe and a book in hand determines Peter who is "dressed in the uniform of the indentured capitalist" (Kolin, 2005, p. 23) where Jerry's "not poorly dressed but carelessly" (Albee, 1960, p. 22) attire suggests his rejection to any establishment code that demands order. Later, through Jerry's chronic interrogation Peter's modern lifestyle is apparent. Peter's wife, daughters, pets, job, salary, fashionable house, favorite authors suggest Peter's typicality as "a modern version, in middle class stereotype of everyman.”(Zimberdo, 1962, p.10) Thus, through Peter's character exposition, the passive modern American cultural code of the post-war American society is manifested. On contrary, Jerry's laughably small room, empty photo frames, eccentric neighbors, pornographic playing card set and extreme 'need' to talk really reveals him as someone who is "living on the margins of society" (Kolin, 2005, p.19). As the play illustrates, he is opposite to Peter, an example of anti-establishment, perhaps the victim of modern establishment and completely unable to conform to it as Peter does. 
The post-war American socio cultural devotion to conservativeness and traditional values are also evident in Peter's characterization when he admits his 'catholic' taste of reading, and when Peter rejects Jerry's interrogation about his private sex life. Thus, Albee shows how the society chooses the individual's choices according to its own fabrication in order to put the people like Peter into the compartmentalization process. As a victim of compartmentalization, Peter wants to confine himself in his self-made prison as he admits "I don't express myself too well" (Albee, 1960, p. 27). To cover up his compartmentalization Peter "desires to build a world of illusion which furnishes an escape from his personal insufficiencies" (Haredasht, Hajjari and Shahidzadeh, 2015, p.15). He shrinks himself from Jerry when Jerry offered his story regarding landlady's dog. Peter can understand neither the reason nor the emotion behind that dog's story. Peter does not even care to listen because "Peter tries to avoid talking about any subject that has real relevance, anything that has roots penetrating the carefully prepared mask which he presents to the world, and even to himself" (Zimberdo, 1962, p.11). Jerry's anti-establishment and countercultural attitude is forbidden for Peter that shows his conformity to Americanization and admittance of the compartmentalization. Vorlicky (1995) says, "Peter's manipulation in the speech act symbolizes... a withdrawal from temporal, spiritual or social reality" (p.125). As a consequence, "Peter does not acknowledge any relationship between his own needs and those of others until his personal survival is challenged" (Vorlicky, 1995, p.128). So, Peter's violent self-defense for his materialistic possession (the bench) seems very natural because the relationship that has been reduced to power struggle also demands conscious sharing, sacrificing and communication with others who are more in need of those. However, the capitalistic American society denies this sharing and sacrificing only to confirm to the constant demand of materials and belongings in modern socio-cultural life. Vorlicky (1995) quotes Bigsby's remark, "the play seems to stand as an indictment of materialism". (p.127)

The materialistic principal of the post-war America infused its culture with a capitalistic patriarchy as depicted through Peter's sharp concern about his masculine identity. For Jerry this is another illusion in which Peter and contemporary Americans like him are entangled. And Jerry thinks "the only way to get through to them is by means of intruding their cage and making them aware of their false belief" (Haredasht, Hajjari and Shahidzadeh, 2015, p.17). Jerry insults Peter's Masculine identity by devaluing Peter's home, wife, children and all possessions. Jerry was "Hoping to jolt Peter out of his gender coded identity into a kind of primal confrontation, Jerry appeals to the 'male animal' within Peter." (Vorlicky, 1995, p.126) Therefore, Jerry tries to probe and confront Peter's masculine identity by taking possession of his regular bench. Through Jerry's voice, “Albee intentionally questions not only Peter's value but those of the capitalistic patriarchy into which American men are socialized.” (Vorlicky, 1995, p.127)

In this test so far, Peter is the representative of the establishment, the conformed and imprisoned American soul while Jerry, the counterculture hero represents the 'other America' which was constantly in struggle with establishment. Jerry's open, self-disclosing statements about his sexual preferences, his anti socio-cultural behavior towards both animal and human being, and his anti-capitalistic existence, all are meant to break the compartments created by society and culture, to reach modern Americanized souls like Peter. Thus, Jerry learns that modesty and being friendly are not enough; so, he applies cruelty to communicate with Peter. Vorlicky's (1995) statement supports this as he says, "in a final effort to connect, Jerry assumes that Peter's other side will respond to the power plays of violence" (p.126) whilst "Jerry on the other hand is seen as desperately desiring to 'know', to reach an understanding with another" (Nilan, 1973, p.55)

Through Jerry's anti-establishment attitude, his incapability to communicate with the establishment and alienation as result, Albee wanted to turn the spotlight towards the other, the disregarded or repressed corner of the post-war American society whose disappointment is represented through Jerry's image. Albee's The Zoo Story echoes out this subversive ambiguous socio-cultural attitude referred as establishment, as well as, show how a countercultural embodiment was also active in the social structure. He also challenges the vision of American audience that is constructed by the made-up illusions.

\section{Re/constructed consciousness through media in The Zoo Story}

The presence of Albee's critical view towards contemporary media in The Zoo Story manifests the dominance of media as a cultural factor, and its power of manipulation in constructing the capitalistic socio-cultural approach. When Peter referred to Time magazine, Jerry commented, “Time magazine is not for blockheads". (Albee, 1960, p.24) Jerry's comment criticizes media's ability of creating boundaries socially and culturally. By creating differences between educated elite class, and the blockheads, the media patronizes the compartmentalization and the so-called normative behavior once again. By compartmentalizing and separating the self, media shapes a complex way of controlling. Thus, media acts like a representative of one portion of society and becomes the voice of heterosexual and normatively structured society. Shams and Pourgiv (2013) elucidates,

"Between the years 1945-1960, America was a prosperous society where the consumer culture urged the Americans to compete for owning luxury items, homes, cars and televisions. Popular television presented an image of idyllic suburban prosperity. The TV shows of the time depicted white middle class nuclear families in which the father was an organization man, the wife looked after the family and home, and the traditional gender roles were maintained" (p.02)

In post war America, by the popularity of television, a massive power to manipulate and subvert the socio-cultural pattern was emerged at that time. Peter admits in The Zoo Story that his family has two televisions in possession, which informs the growth and consumption of this machine regarded as a materialistic factor that confirms one's social class and cultural identity. Television created a class consciousness "in the USA, at least, television viewing integrated 
viewers into capitalistic society, by reinforcing its norms and marginalizing deliberative analysis" (During, 2005, p.115). Referring to Theodor Adorno's argument on television During (2005) states again, "television reduced its audience's capacities to reflect on and critique society and culture" (p.115). As a representative of the 'establishment', Peter's life is also impregnated with television, and other media representations of American society that constructed him to conform more, and be unconscious about subjects like Jerry. Television imprints a profound image of standardized world in Peter's life as well as the class conscious public. As During (2005) illustrates, "television possess a great power of seduction that the distinction between its dream world and the reality becomes confused" (p.115). The popular television programs in post war decades were designed to distract the public eye from major critical issues rising inside of society. Issues like, civil rights, women rights, minor community, religious preferences and other divergent issues were being controlled politically at that time, where media and television were used as a weapon to represent the 'affluence' America. This fabrication was meant to disregard those issues, and to pretend they do not exist at all. In Support to that, Bailey (2005) states, "While images presented by entertainment television on family, various comedy TV serials fostered the idea that the American life style made people happy, the real world did not reflect these idealistic family portraits". (p.34). Therefore, the people were manipulated to live upon television's impossible standards. And Peter, who lives a modern standard Americanized life style, in a sense, is inflicted by the television and media's politicized representation of American hegemonic ideologies. Definitely, in the process to maintain that life style and fantasized world, consumerism and capitalism confirmed their place inside the socio-cultural pattern. Jerry criticizes this capitalistic media-represented fantasized world, when he comments on Peter's knowledge about pornographic playing cards, "it's that when you're a kid, you use the cards as a substitute of a real experience and when you're older you use real experience as a substitute for the fantasy" (Albee, 1960, p.32). In both ways, the fantasy remains the same and the demand and consumption of that fantasy is constant.

Dr.Turki (2009) verifies, "to be murdered is more effective in media than to commit suicide" (p.9). Jerry's urgency towards media coverage of his own death in a public place is presented as a protest by Albee. Jerry's attempt to be seen in TV and published in news papers is the only way that he found to communicate with establishment and to be regarded by it as well. Dr.Turki (2009) remarks, "he wanted someone to kill him so that his death will be reported in the media, and in this way he will be identified" (p.9). Jerry's dead body is the manifestation of the certain devalued social class that is, struggling with the modern capitalistic structure, patriarchy and heteronormativity. So, his death news, which may convey reasons also, would be a possible way to wake up the American socio-cultural consciousness that is spell-bounded and fantasized by the authority through media.

\section{Sexuality in The Zoo Story}

The Zoo Story illustrates the world as a 'zoo', where an individual's activity, especially sexuality, is limited to within the so-called fixed and universal 'normative bars' of the society that tries to define an individual from its own perspectives and interests rather than taking or allowing the individual's perception and choices. Instead of considering individual's sexuality "as a fluid, fragmented, dynamic collectivity of possible sexualities" (Tyson, 2006, p.335), the society tries to define individual's sexuality through 'heterosexuality' as a part of social dominance, and hegemony. In this 'zoo' world, "heterosexuality is cultivated through prohibition, and these prohibitions take as one of their objects homosexual attachments, thereby forcing the loss of those attachments" (Butler, 1997, p.136). Jerry's homosexual identity and his alienation caused by it, is remarked by Jaf and Zaihong (2014) stating, "Alienating a person 'a being' for their sexual preference is the root cause of social discrimination and labeling of 'otherness" " (p.462). Thus, for both Albee and Jerry, this heterosexual world only sees other orientations of sexual desires of an individual as a 'pervert' or 'savage' activity, and tries to give a sense of 'shame' to its very own citizens, if their choice of determining their own sex and sexuality are not matched with the predefined social sexual behavior, for instance- Jerry downs his "head in shame that puberty was late...I (Jerry) was homosexual.” (Albee, 1960, p.31)

With the intention of implementing heterosexuality as a normative sexual behavior, society tries to introduce its intention through many mediums as like 'a pack of pornographic playing cards' (Albee, 1960, p.29) that gives infantile sexual pleasure and fantasy to the kids or juvenile ones, as a matter of fact, they are very much suggestive to drive the kids' psychology towards heterosexual pleasure. On contrary, when this heterosexual pleasure fails to meet up the desires of an individual, or, an individual makes his/her own choice, he or she becomes alienated from the society, as like, Jerry who lives at 'a laughably small room' in a 'village'[Peter's mockery] (Albee, 1960, p.28). Jerry's heterosexual parents' disastrous marriage sets a disharmonic overtone in his life, and his so-called savage and pervert nature make him a national enemy, who is very infectious and dangerous for the 'heterosexual' society.

Because of one's sexual behavior, the society keeps aside its individuals like Jerry from its mainstream face, and puts a shadow of discrimination between them and societal functions in its so-called free and open world. Bona (2004) elucidates,

"In the United States after 1950, Joseph McCarthy's House Un-American Activities Committee (HUAC) classified homosexuals along with communists as dangerous, claiming that they were at risk of blackmail and therefore potential subversives who should be ostracized from government or made subject to punishment through incarceration." (p.210)

Albee puts an echo of the contemporary society in The Zoo Story that shows how the executive order 10450 of 1953 , a bill uses sexual perversion as a ground to dismiss homosexual people from the federal and government position, affects the life style of the people like, Jerry, and being marginalized. Upon the basis of sexuality, the McCarthy commission declares a war against homosexual people and provides more opportunities to the Peter-type people, who enjoy much 
more benefits by selling their heterosexual attitudes or killing the rights of others. As a counterpart of Jerry, Peter is a representative of heterosexual community, who has a typical family and his own zoo. Though homosexuality 'seems perfectly simple to' Peter, he doesn't wish to negotiate or give same status to Jerry, for example- as a means of power struggle, Peter does not wish to give up the same 'bench' to Jerry, which he (Peter) thinks as his own belonging.

The 'zoo' world is so eager and blind to take control over its own animals. It tries to define individual's choices in their own perspectives, whether it works or not, they simply try to impose their own dogmas as bars. Sometimes, people get so much occupied by themselves to believe these so-called norms that they cannot understand other's emotions that can be hurt in attempt to fulfilling those norms. In this drama, Hussein (2007) confirms, "She (the landlady) wants to use Jerry as the tool to satisfy all her sexual desire" (p.61). And she does it every day by repressing Jerry's preference. Jerry becomes "the object of her (landlady) sweaty lust" (Albee, 1960, p.33). Here, the landlady's mind is preoccupied by the fixed behavior that implies a man can find his pleasure in a woman's body and vice versa. So, although Jerry was longing for human contact but he denies the landlady, because, "evasion on the part of Jerry and naïve imaginings of nonexistent sexual interactions cannot be deemed as human relations" (Hussein, 2007, p.61). Jerry is also in a hurry when he utters "I was queer... [Very fast] ...queer, queer, queer" (Albee, 1960, p.31). This fast paced talk of Jerry indicates the anomaly of the current societal functions where expressing one's own preference is intimidated. Therefore, Jerry being a queer is subjugated because, "to queer is to challenge heterosexuality as a naturalized social-sexual norm and ...hegemony of 'straight' ideology" (Jaf and Zaihong, 2004, p.462). The "normal' society considers this as 'abnormal'. Thus, Jerry is thrown by the society in a place where "animals are indifferent to me (Jerry)...like people" (Albee,1960, p.35). Jerry is surrounded by a vacuum where he has to shout to someone in a park to make an interaction. Jerry shouts as, "I've been to the zoo. [PETER doesn't notice.] I said, I've been to the zoo. MISTER, I'VE BEEN TO THE ZOO!" (Albee, 1960, p.23). It seems that Jerry is that animal who lives in a cage where he has the so-called freedom within his confinement, in Jerry's voice:

"I went to the zoo to find out more about the way people exist with animals, and the way each other, and with people too. It probably wasn't a fair test, what with everyone separated by bars from everyone else, the animals for the most part from each other, and always the people from the animals. But, if it's a zoo, that's the way it is." (Albee, 1960, p.43)

As a counterpart of Jerry and a possessor of heterosexual societies, Peter regards the 'bench' as his own property as like his society sees the determination of gender and sexual behavior as its own rights. While there is an option to have a bench for each of them, he is 'quivering' and says that Jerry has "no right to take it away from" him. As like Peter, the contemporary society has no concern about "what other people need" (Albee, 1960, p.46) rather they try to 'fight' for the mere things and convert it into a power struggle. Homophobia grabs 'GROWN-UP' Peter so much that he tries to call policeman who are actually "all over on the west side of the park chasing fairies down from trees or out of the bushes". (Albee, 1960, p.45) Additionally, 'fairies' is used as a slang word for queer people at that contemporary time. It seems Edward Albee's Jerry tries to put his own very existence in front of Peter fostered by the idea, "we're here, we're queer - get used to it" (note 2), a famous queer slogan. Likewise, Jerry's action appears to be inspired by Camus' celebrated philosophy, "I rebel, therefore, we exist" as he fights for his existence and brings out the "animal' part of Peter by being killed in Peter's hand. Therefore Jerry actually dragged Peter down to his (Jerry) own level, designed by peter's society, to make him oriented with the queer identity.

\section{Religious issues in The Zoo Story}

The 'zoo' world uses religion as one of the most effective bars corresponding to command to create control over people. Hussein (2007) comments, "Albee here, in the voice of his alienated character Jerry, expresses his indictment and accusation of the whole world including God" (p.63). On contrary, Albee depicted Peter as a believer in conservative religion that only permits heterosexual orientation and sees homosexual orientation as a sin to humanity. His society uses religion as a tool to separate the homosexuals from the society by giving different interpretations of the Biblical references. The contemporary religious institutes condemn homosexuality and say it is detestable, while Bible places love instead of taking love as the fulfillment of law. It bears the essence of heterosexual world, and tries to make its believers to believe in heterosexuality as the only rightful sexual orientation. As many churches condemn homosexuality, homosexual people have found themselves in a state where they have no religious identity because their act is so-called sinful. Therefore, this enforced Godless identity leads Jerry to probe God as Singh (1987) comments, "The Zoo Story suggests ... man's search for God" (p.24). Nevertheless, Jerry's realization is that the God who has created this universe and man, now has "turned his back from the whole thing" (Albee, 1960, p.37), leaving Jerry as an outcast in the post-war social and religious establishment. A heterosexual society formulates its codes by quoting the bible, for example, "But since there is so much immorality, each man should have his own wife, and each women her own husband" (1 Corinthians 7:2) (note 3), whereas it forgets "God shows his love for us in that while we were still sinners, Christ died for us" (Romans 5:8) (note 4). According to Zimberdo (1962), Jerry is interpreted as a Christ-figure who wanted to confirm "salvation through sacrifice" (p.16). Through his death he wanted to shiver the whole 'normal' society, Peter in particular, which denies to share God's mercy equally among all subjects, whereas, "Jerry is seen as one filled with compassion for his fellow beings, willing to sacrifice himself to save them." (Nilan, 1973, p.55)

Albee's Jerry is not like the church or hypocrite society that only uses religion to oppress human soul and cage them behind the bars; rather he mentions 'love' for several times that is an act of God in order to deal with the current misunderstanding and miscomprehending situations. Jerry emphasizes on making "A START" for the sake of love, "even with God", to clarify confusions and demolish the bars that stood amongst the people. Jerry sees God as "A 
COLOURED QUEEN WHO WEARS A KIMONO WHO CRIES WITH DETERMINATION BEHIND HER CLOSED DOOR" (Albee, 1960, p.39) that means God is in everywhere and in every singular identity, not like the religious institutionalized God who has abandoned his creatures because of 'unrighteous' sexual orientation. Albee's Jerry makes an echo of queer people's voices who [Jerry] asks the society "to understand and just possibly be understood" to start "a beginning of an understanding". (Albee, 1960, p.39)

Jerry makes a few sarcastic comments in the play about the institutionalized God who is very much institutionalized by the church and authorities, for example- he told the landlady he would 'pray' while he doesn't know how to 'pray', uses words like 'Amen' as if he is citing from Bible, and 'goddamned' to mock at Peter's belief. At the end of the play, Jerry is mocking with 'a combination of scornful mimicry and supplication' and says "Oh...my...God". (Albee, 1960, p.49). Singh (1987) asserts, "The last we hear from him is a pitiful offstage howl "OH MY GOD”. Thus the absurdity of survival in the Twentieth century is dramatized" (p.24). This elucidates that uninstitutionalized Jerry is killed by the institutionalized Peter, whose God cannot help him to control his animal side, nor, it can save Jerry from being killed in the hand of Peter. That is why, in the ending scene, instead of taking the responsibility of the situation or taking Jerry to the hospital, Peter flees away from the situation and seeks forgiveness to his institutionalized God.

\section{Conclusion}

Edward Albee's The Zoo Story reflects the anomaly of the contemporary society where an individual's soul is distorted and disorientated by imposing different social norms and regulations. The society tries to use the compartmentalization of souls in order to put a human soul within a cage to establish its so-called norms and heterosexual attitude. The patriarchal attitude is so much rotten in the structure of the society that it tries its every singular opportunity to oppress others choices, especially, in sexual orientations. Thus, The Zoo Story tries to grab the voice of Rousseau (2003), "man was born free, and everywhere he is in chains." (p.102)

To conclude, in the realm of absurdity created through The Zoo Story, Albee tries to show that how the post-war American culture was infused with Americanization involving compartmentalization of soul, conformity to capitalism, patriarchy and dehumanization of American society, and heteronormativity, under the command of an anti-communist media-constructed socio-political practice. By echoing these, Albee emphasizes on love as Jerry did to minimize the social and cultural marginalities and discriminations among different social classes to create a new America which is truly free and open for all in every possible senses. Additionally, Albee questions to his audience through Jerry's voice, "if we can so misunderstand, well then, why have we invented the word love in the first place?" (Albee, 1960, p.40), and expects, "the opportunity for living with an awakened sense of private responsibility and public commitment" (Bryer and Harting, 2010, p.18) to every American citizen.

\section{References}

Albee, E. (1960). The Zoo Story: A Play in One Scene for William Flanagan. New York, NY: Grove Press.

Bailey, L. M. S.( 2005). Absurdly American: Rediscovering the Representation of Violence in The Zoo Story. In Bruce J. Mann (Ed.), Edward Albee: A Case Book. (pp. 33-44) New York: Taylor and Francis Books.

Barret, C. K. (2013). The First Epistle to the Corinthians. Grand Rapids, Michigan, USA: Baker Publishing Group.

Bell, J. (2004). American Drama in the Postwar Period. In Josephine G. Hendin (Ed.) A Concise Companion to Postwar American Literature and Culture. (pp. 110-148). Oxford, Uk: Blackwell Publishing.

Bona, M. J. (2004). Gay and Lesbian Writing in Post-World War II America. In Josephine G. Hendin (Ed.) A Concise Companion to Postwar American Literature and Culture.(pp. 210-237). Oxford,UK: Blackwell Publishing.

Bryer, J. R. and Harting, M. C. (2010) Facts on File Companion to American Drama. (2 ${ }^{\text {nd }}$ Ed) . New York: Facts on File, Inc.

Butler, J. (1997). The Psychic Life of Power. Stanford: Stanford University Press.

Camus, A. (2012). The Rebel: An Essay on Man in Revolt. (Anthony Bower, Trans.). New York: Knopf Doubleday Publishing Group. (Original work published in 1956)

During, S. (2005). Cultural studies: A Critical Introduction. Abingdon, Oxon, USA: Routledge.

Harehdasht, H.A., Hajjari, L., \& Shahidzadeh, Z. S. (2015). Illusion and Reality in Edward Albee's The Zoo Story. Studies in Literature and Language, 10(6), 15-21. DOI: 10.3968/7182.

Hussein, W. A. (2007). The Zoo Story: Character Alienation. Journal of the College of Arts, University of Basrah, 43,58-67. Retrieved from http://www.iasj.net/iasj?func=fulltext\&aId=50455

Horn, B. L. (2009). Edward Albee: A Research and Production Source Book. USA: Praeger Publisher, Green Book Publishing Group.

Jaf, S. \& Zaihong, Z. (2014). Social Detachment: A Cause of Alienation in Edward Albee's The Zoo Story. Journal of International Academic Research for Multidisciplinary, 2(9),459-467. Retrieved from http://www.jiarm.com/OCT2014/paper18382.pdf

Karl, F. R. (2004). The Fifties and after: An ambiguous Culture. In Josephine G. Hendin (Ed.). A Concise Companion to Postwar American Literature and Culture. (pp. 20-71). Oxford, Uk: Blackwell Publishing. 
Kolin, P. C. (2005). Albee's Early One Act Plays: "A new American playwright from whom much is to be expected". In Stephen Bottoms (Ed.) The Cambridge Companion to Edward Albee. (pp. 16-38). New York: Cambridge University Press.

Murray, J. (1997). The Epistle to the Romans. Grand Rapids, Michigan, USA: William B. Eerdmans Publishing Company

Nilan, M. M.(1973). Albee's The Zoo Story: Alienated Man and the Nature of Love. Modern Drama 16(1), 55-59. University of Toronto Press. Retrieved July 9, 2014, from Project MUSE database.

Rousseau, J. J. (2003). On the Social Contract. (G. D. H. Cole. Mineola Trans.). New York: Dover Publications, Inc. (Original work published in 1762).

Shams, P. \& Pourgiv, F. (2013) Power Struggle in The Zoo Story: A Performance of Subjectivity. Fe Dergi 5(1). Retrieved from: http://cins.ankara.edu.tr/9_1.html.

Turki, H. I. (2009). The Caged Soul: A Study of Edward Albee's The Zoo Story. Al-fatih Journal, 40, 1-12. Retrieved from http://www.iasj.net/iasj?func=fulltext\&aId=16901

Tyson, L. (2006). Critical Theory Today: A User Friendly Guide. (2 ${ }^{\text {nd }}$ Ed.) New York,NY: Routledge.

Vorlicky, R. (1995). Silence Violence and the Drama of Abuse. In R. Vorlicky and A. Arbor (Ed.), Act like a Man: Challenging Masculinities in American Drama. (pp. 87-132). USA: The University of Michigan Press.

Zimbardo, R. A.. (1962). Symbolism and Naturalism in Edward Albee's The Zoo Story. Twentieth Century Literature, 8(1), 10-17. http://doi.org/10.2307/440743

\section{Notes}

Note 1. A phrase from the national anthem of USA written by Francis Scott Key.

Note 2. A slogan introduced by Queer Nation, an LGBTQ activist organization founded in March 1990, New York city. Note 3. Cited from Barret, C. K. The First Epistle to the Corinthians. See works cited.

Note 4. Cited from Murray, John. The Epistle to the Romans. See works cited. 